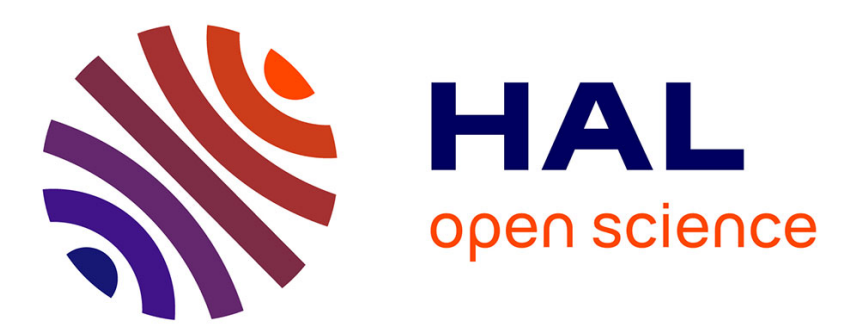

\title{
Dependence of model-based extreme flood estimation on the calibration period: the case study of the Kamp River (Austria)
}

Pierre Brigode, Emmanuel Paquet, Pietro Bernardara, Joël Gailhard, Federico Garavaglia, Pierre Ribstein, François Bourgin, Charles Perrin, Vazken

\author{
Andréassian
}

\section{To cite this version:}

Pierre Brigode, Emmanuel Paquet, Pietro Bernardara, Joël Gailhard, Federico Garavaglia, et al.. Dependence of model-based extreme flood estimation on the calibration period: the case study of the Kamp River (Austria). Hydrological Sciences Journal, 2015, Special issue: Modelling Temporallyvariable Catchments, 60 (7-8), pp.1-14. 10.1080/02626667.2015.1006632 . hal-01164840

\author{
HAL Id: hal-01164840 \\ https://hal.science/hal-01164840
}

Submitted on 17 Jun 2015

HAL is a multi-disciplinary open access archive for the deposit and dissemination of scientific research documents, whether they are published or not. The documents may come from teaching and research institutions in France or abroad, or from public or private research centers.
L'archive ouverte pluridisciplinaire HAL, est destinée au dépôt et à la diffusion de documents scientifiques de niveau recherche, publiés ou non, émanant des établissements d'enseignement et de recherche français ou étrangers, des laboratoires publics ou privés. 


\title{
Dependence of model-based extreme flood estimation on the calibration period: the case study of the Kamp River (Austria)
}

\author{
P. Brigode ${ }^{1}$, E. Paquet ${ }^{2}$, P. Bernardara ${ }^{3}$, J. Gailhard ${ }^{2}$, F. Garavaglia ${ }^{2}$, P. Ribstein ${ }^{4}$, F. \\ Bourgin $^{1}$, C. Perrin ${ }^{1} \&$ V. Andréassian ${ }^{1}$. \\ ${ }^{1}$ UR HBAN, Irstea, Antony, France \\ ${ }^{2}$ DMM, DTG, Électricité de France, Grenoble, France. \\ ${ }^{3}$ LNHE, R\&D, Électricité de France, Chatou, France. \\ ${ }^{4}$ Sorbonne Universités, UPMC Univ. Paris 06, UMR 7619 METIS, Paris, France. \\ pierre.brigode@irstea.fr
}

Received 20 January 2014; accepted 25 November 2014

Accepted author version posted online: 13 Jan 2015.Published online: 16 Jun 2015.

Editor Z.W. Kundzewicz; Associate editor A. Viglione.

\begin{abstract}
The Kamp River is a particularly interesting case study for testing flood frequency estimation methods, since it experienced a major flood in August 2002. Here, this catchment is studied in order to quantify the influence of such a remarkable flood event on the calibration of a rainfall-runoff model, in particular when it is used in a stochastic simulation method for flood estimation, by performing numerous rainfall-runoff model calibrations (based on split-sample and bootstrap tests). The results confirmed the usefulness of the multi-period and bootstrap testing schemes to identify the dependence of model performance and flood estimates on the information contained in the calibration period. The August 2002 event appears to play a dominating role for the Kamp River, since the presence or absence of the event within the calibration sub-periods strongly influences the rainfall-runoff model calibration and the extreme flood estimations that are based on the calibrated model.
\end{abstract}

Key words: Non stationarity; IAHS workshop; model calibration and evaluation; SCHADEX, extreme floods, bootstrap.

\section{Dépendance des estimations de crues extrêmes (basées sur un modèle pluie- débit) à la période de calage: étude de cas de la rivière Kamp (Autriche)}

Résumé La rivière Kamp est un cas d'étude particulièrement intéressant pour le test de méthodes de prédétermination des crues, puisqu'elle a vu une crue exceptionnelle se produire en août 2002. Dans cet article, nous étudions ce bassin versant pour quantifier l'influence de ce type de crue remarquable sur le calage d'un modèle pluie-débit, en particulier lorsqu'il est utilisé dans une méthode de simulation stochastique pour la prédétermination des crues. Pour cela, nous réalisons de nombreux calages du modèle pluie-débit (en nous basant sur des tests de bootstrap et sur des périodes indépendantes). Les résultats obtenus confirment l'utilité des procédures de calages multi-périodes et de «calages bootstrap " pour identifier la dépendance des performances des modèles hydrologiques et des estimations de crues extrêmes aux informations contenues dans les périodes de calage. L'événement de 2002 apparait jouer un rôle dominant pour la rivière Kamp, puisque la présence de l'événement au sein des périodes de calage influence fortement le calage du modèle pluie-débit et l'estimation des crues extrêmes reposant sur le modèle calé. L'ensemble des jeux de paramètres obtenus avec des périodes de calages ne contenant pas l'épisode de 2002 produit des estimations de crues extrêmes systématiquement plus fortes que celles obtenues avec les autres jeux de paramètres.

Mots clé : Non stationnarité ; Atelier AISH ; calage de modèle et évaluation; SCHADEX ; crues extrêmes ; bootstrap. 


\section{INTRODUCTION}

\subsection{The challenge of hydrological variability}

The calibration of rainfall-runoff models in the context of a changing climate is currently the subject of an intense discussion in the hydrological modelling community (e.g. by Peel \& Blöschl, 2011; Muñoz et al., 2013; Montanari et al., 2013; Hrachowitz et al., 2013 and Thirel et al., 2014). Indeed, observed hydrometeorological series (precipitation or streamflow for example) used for model calibration are subject to significant variability over time (Milly et al., 2008). This variability could be induced by sudden physiographic changes in the catchment (e.g. forest fire, dam building), climatic condition changes (e.g. air temperature rising) and/or long-term fluctuations being barely detectable by statistical tests (Koutsoyiannis, 2006; Montanari, 2012).

Hydrological variability challenges the usual calibration approach - traditionally assuming stationary or at least representative hydro-climatological conditions - which consists in using the entire record period for identifying one or several optimal parameter sets. Several studies, based on the split-sample test proposed by Klemeš (1986), investigated the sensitivity of rainfall-runoff simulations to the characteristics of the calibration period (e.g. Donnelly-Makowecki \& Moore, 1999; Seibert, 2003; Vaze et al., 2010; Merz et al., 2011; Coron et al., 2012; Brigode et al., 2013a). Gharari et al. (2013) recently suggested estimating calibration performance over different sub-periods, in order to identify parameter sets with time-consistent performance, thereby reducing the over-calibration problem (Andréassian et al., 2012). Time-varying sensitivity analysis such as the DYNamic Identifiability Analysis (DYNIA, Wagener et al. (2003)) have also been proposed to identify "informative regions with respect to model parameters" (Wagener \& Kollat, 2007) and to link particular hydro-climatic conditions with time-varying dominant rainfallrunoff model parameters (Herman et al., 2013).

\subsection{The information content of extreme events}

The observed hydro-meteorological variability affects mean values as well as extreme values. For instance, Ward et al. (2014) recently showed that El Niño Southern Oscillations (ENSO) significantly influence the flood intensity of daily annual peak. Interannual variability could also be characterized by the observation of outliers within the record period, i.e. the "outlying observation that appears to deviate markedly from other members of the sample in which it occurs" (Grubbs, 1969). Such outstanding values have to be taken into account, since they provide valuable information about the extreme hydrological behavior of the studied catchments (Laio et al., 2010). In a statistical framework, methods such as resampling techniques (Katz et al., 2002) can be used to quantify the sensitivity of the extreme-quantile estimation to these observed rare events.

Nevertheless, in the context of rainfall-runoff model calibration, quantifying the sensitivity of the model's results to such rare events is more challenging. Berthet et al. (2010) showed that only a limited number of time steps truly influences the values of the quadratic calibration criteria usually used for rainfall-runoff model calibration (like Nash \& Sutcliffe (1970) Efficiency or Root-Mean-Square Deviation scores). 
104 Moreover, Perrin et al. (2007) and Seibert \& Beven (2009) highlighted that a limited number of streamflow values can contain a significant amount of hydrological information, while Beven \& Westerberg (2011) suggested that some periods within the observation records could even be disinformative for the models. Singh \& Bárdossy (2012) and Singh et al. (2012) suggested identifying a limited number of events on which the calibration should be performed, using the statistical concept of

The challenge of rainfall-runoff model calibration in a changing climate has been recently studied in a workshop during the 2013 International Association of Hydrological Sciences (IAHS) General Assembly in Göteborg, Sweden, where hydrological modellers were asked to calibrate their models over several selected catchments (Thirel et al., 2014, this issue). Participants were provided a calibration and evaluation protocol as well as a selection of 14 "changing catchments" showing different observed changes such as temperature increases, dam building and landcover modification.

Among these 14 catchments, the Kamp River at Zwettl $\left(622 \mathrm{~km}^{2}\right)$ located in northern Austria is a particularly interesting case study, since (i) a significant increase of more than $1{ }^{\circ} \mathrm{C}$ of the catchment's air temperature has been estimated over the last 30 years (Thirel et al., 2014, this issue) and (ii) it experienced a major flood event in August 2002, which has been extensively studied over the last few years (e.g. Komma et al., 2007; Viglione et al., 2010; Viglione et al., 2013). The August 2002 event, which caused major flooding in different regions of central Europe (Blöschl et al., 2013), resulted in an estimated peak flow of $460 \mathrm{~m}^{3} / \mathrm{s}$, which is three times higher than the second largest flood observed over the 1951-2005 period (Viglione et al., 2013). The influence of this event has already been studied by Viglione et al. (2013) in the context of flood frequency analysis, showing that this event strongly influences the extreme flood estimation if no additional information (e.g. historical data) is used. On this catchment, Brigode et al. (2014) also illustrated the strong influence of this event on extreme rainfall estimation and on extreme flood estimation performed with a stochastic flood simulation method.

\subsection{Scope of the paper}

This paper aims at (i) applying the calibration protocol proposed by the 2013 "hydrology under change" IAHS workshop within the context of extreme flood estimation based on a rainfall-runoff model, (ii) comparing the results obtained using the workshop calibration protocol to the one proposed by Brigode et al. (2014) based on bootstrap resampling and (iii) quantifying the influence of the 2002 event on rainfall-runoff model calibration. As in Brigode et al. (2014), the SCHADEX method (Simulation Climato-Hydrologique pour l'Appréciation des Débits EXtrêmes - Hydroclimatic simulation for the estimation of extreme flows) detailed by Paquet et al. (2013) has been applied over the Kamp catchment, considering sub-periods for the calibration of the MORDOR rainfall-runoff model. 
The Kamp catchment at Zwettl is one of the 14 "changing catchments" selected for the IAHS workshop and described in detail by Thirel et al. (2014, this issue). Daily precipitation, temperature and streamflow series have been supplied and are available for the 1976-2008 period. Additionally, elevation data have been extracted from the SRTM 90m data set (Jarvis et al., 2008).

Figure 1 illustrates the hydroclimatic context of the Kamp catchment at Zwettl, a $622 \mathrm{~km}^{2}$ catchment located in northern Austria. Catchment elevation ranges from around 500 to $1,000 \mathrm{~m}$ a.s.l, with the highest elevation areas located in the southern and western parts of the catchment. The daily streamflow and precipitation series plotted in the upper part of Figure 1 clearly show that the August 2002 flood is not comparable to other observed floods, both in terms of observed precipitation amount and flood magnitude. Due to this extreme event, the 2001-2002 hydrological year has the largest precipitation and runoff annual mean within the 1976-2008 period. On average, the mean annual precipitation and runoff are around $800 \mathrm{~mm}$ and $300 \mathrm{~mm}$, respectively, on the Kamp catchment. Precipitation and runoff have clear seasonal behaviours in this region, with the highest precipitation amount observed during summer (typically from June to August) and the highest streamflow amount observed during the March to April month, due to snowmelt. Large floods are usually observed on this catchment during the July to August period, mainly produced by intense rainfall events. Note that snow processes are important on this catchment, since floods are also observed during rain-on-snow or snowmelt events in this region (Viglione et al., 2010).
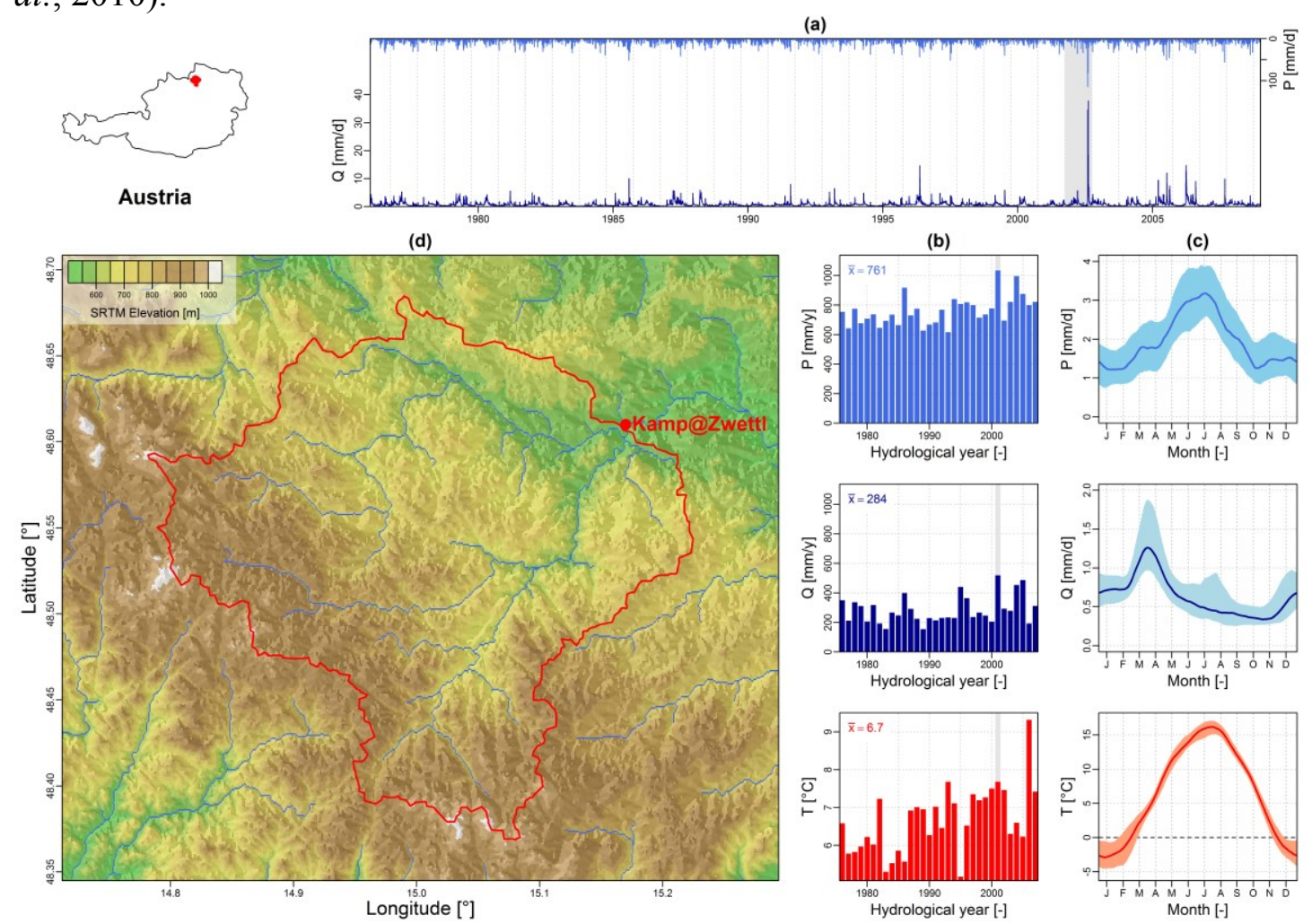

Fig. 1 Hydroclimatic context of the Kamp River at Zwettl catchment: (a) observed daily streamflow and precipitation time series, (b) streamflow, precipitation and temperature mean annual series, (c) streamflow, precipitation and temperature monthly regimes, and (d) SRTM elevation data (Jarvis et al. 2008). 


\section{METHOD}

\subsection{The SCHADEX flood simulation method}

The SCHADEX method (Paquet et al., 2013) is a stochastic flood simulation method developed and applied by Électricité de France (EDF) for the design of dam spillways. It has been applied to more than 80 catchments over France and elsewhere, for example in Austria, Canada and Norway (Lawrence et al., 2014; Brigode et al., 2014).

SCHADEX is a semi-continuous stochastic flood simulation method that generates, for a given catchment, a large number of floods, which result from the combination of two hazards: (i) the rainfall hazard and (ii) the catchment saturation hazard:

i. Rainfall events are randomly drawn using a rainfall probabilistic model, the Multi-Exponential Weather Pattern distribution (Garavaglia et al., 2010). This rainfall probabilistic model is based on a seasonal and weather pattern subsampling of observed rainfall series. The five weather pattern classification proposed for Austria by Brigode et al. (2013b) is used for the Kamp catchment.

ii. Catchment saturation conditions are not explicitly described as a random variable but are instead generated by a continuous rainfall-runoff simulation over a long record period and thus implicitly represented by the internal variables of the rainfall-runoff model.

The MORDOR rainfall-runoff model (Garçon, 1999; Andréassian et al., 2006) is used to perform the continuous rainfall-runoff simulation used for the description of the catchment saturation conditions and also to transform a given rainfall event falling over a given catchment into a flood event.

For each studied catchment, the SCHADEX simulation process generates around two millions of simulated floods, resulting from the combinations of different rainfall events with different catchment saturation conditions. A distribution of simulated flood events is built to provide estimates of extreme flood quantiles, such as the 1,000-year return period flood (noted $\mathrm{Q}_{1000}$ ).

In this study, only the MORDOR parameter set will change according to the calibration periods. The entire record period will be considered for the estimation of the rainfall probabilistic model parameters and for the computation of a modelled distribution of catchment saturation conditions.

\subsection{The MORDOR rainfall-runoff model}

MORDOR is a conceptual rainfall-runoff model developed and intensively used by EDF for operational hydrology in different contexts such as flood forecasting (e.g. Zalachori et al., 2012), low-flow forecasting (e.g. Mathevet et al., 2010; Nicolle et al., 2014) and flood frequency estimation (e.g. Paquet et al., 2013). The different components of the hydrological cycle are represented through four reservoirs within MORDOR: (i) a rainfall excess/soil moisture accounting store (noted U) contributing to actual evaporation and to direct runoff, (ii) an evaporating store (noted Z) filled by part of the indirect runoff component and contributing to actual evaporation, (iii) an 
intermediate store (noted L) determining the partitioning between direct runoff, 230 indirect runoff and percolation to a deep storage reservoir and (iv) a deep storage 231 reservoir (noted $\mathrm{N}$ ) determining baseflow. Last, a unit hydrograph is used for routing

Required inputs of the MORDOR model are air temperature and precipitation series. With the snow component, MORDOR has 22 free parameters, while it has 11 parameters without the snow component. In this study, the snow component parameters were fixed after a first MORDOR calibration over the entire record period, with an objective function combining classical Nash \& Sutcliffe (1970) efficiency (NSE) with a criterion minimizing the difference between observed and simulated mean annual streamflow. This objective function aims at having snow component parameters inducing good day-to-day performance of the rainfall-runoff model and also good model performance in terms of simulated streamflow volume over the entire record period. The volume difference and NSE score obtained with this MORDOR parameter set over the $1977-2008$ period are $-0.1 \%$ and 0.85 respectively. Table 1 summarizes the name, role and unit of the 11 free parameters calibrated in this study and each parameter's prior ranges. These parameters are estimated using an automatic optimization scheme developed by EDF and based on a genetic algorithm, a strategy commonly used in hydrological modelling since the 1990s (e.g. Wang, 1991; Franchini, 1996; Wang, 1997). It has been shown to perform as well as other algorithms such as the SCE-UA (Duan et al., 1992) over numerous catchments by Mathevet (2005).

Table 1 Description of the 11 free parameters of the MORDOR model to be calibrated over the Kamp River at Zwettl catchment.

\begin{tabular}{lll}
\hline Name & Description (and unit) & Range \\
\hline fe1 & Parameter linked to potential evapotranspiration [-] & $0.0005 \leq \mathrm{X} \leq 0.1$ \\
fe3 & Parameter linked to potential evapotranspiration [-] & $-7 \leq \mathrm{X} \leq 0$ \\
k11 & Percolation coefficient 1 of the L reservoir [-] & $0.1 \leq \mathrm{X} \leq 0.9$ \\
k12 & Percolation coefficient 2 of the L reservoir [-] & $0.1 \leq \mathrm{X} \leq 0.9$ \\
$\mathrm{dn}$ & Percolation coefficient of the N reservoir [-] & $1 \leq \mathrm{X} \leq 999$ \\
$\mathrm{exn}$ & Exponent of the recession limb of the N reservoir [-] & $1 \leq \mathrm{X} \leq 8$ \\
$\mathrm{ftr} 1$ & Parameter linked to the routing function [-] & $0.5 \leq \mathrm{X} \leq 10$ \\
$\mathrm{ftr} 2$ & Parameter linked to the routing function [-] & $0.5 \leq \mathrm{X} \leq 6$ \\
$\mathrm{U}_{\mathrm{MAX}}$ & Maximum capacity of the U reservoir [mm] & $30 \leq \mathrm{X} \leq 200$ \\
$\mathrm{~L}_{\mathrm{MAX}}$ & Maximum capacity of the L reservoir [mm] & $30 \leq \mathrm{X} \leq 200$ \\
$\mathrm{Z}_{\mathrm{MAX}}$ & Maximum capacity of the Z reservoir [mm] & $30 \leq \mathrm{X} \leq 200$ \\
\hline
\end{tabular}

\subsection{MORDOR rainfall-runoff model calibration strategies}

The objective function used for the calibration of the MORDOR rainfall-runoff model (noted $\mathrm{OBJ}_{\mathrm{EDF}}$ and given in Equation 1) is a combination of two NSE scores: (i) the NSE score computed with observed and simulated streamflow time series and (ii) the NSE score computed with observed and simulated cumulative distribution functions of streamflow series (noted $\mathrm{NSE}_{\mathrm{CDF}}$ ). This combination allows a good trade-off between the day-to-day performance of the rainfall-runoff model and the model performance regarding the highest observed streamflow values (Paquet et al., 2013). It has been recommended within the context of continuous flood simulation (Lamb, 1999). This objective function is commonly used for the calibration of the MORDOR rainfall-runoff model within the SCHADEX method applications (e.g. Paquet et al., 2013; Lawrence et al., 2014; Brigode et al., 2014). For each MORDOR calibration, 
only the optimal parameter set in terms of the $\mathrm{OBJ}_{\mathrm{EDF}}$ objective is considered further.

Three different calibration options were considered, as illustrated in Figure 2:

i. The MORDOR model was calibrated over the entire record period, leading to a parameter set considered as the reference set (noted CP for complete period in the following).

ii. MORDOR was calibrated over the five 6-year sub-periods selected in the workshop test protocol (Thirel et al., 2014, this issue). These five parameter sets are noted P1 to P5 parameter sets in the following. The August 2002 flood event is included in the P5 sub-period.

iii. One hundred independent calibrations (noted BST1, BST2, .., BST100) were made over 25-year sub-periods, identified through a block-bootstrap method described by Brigode et al. (2014). For each of the 100 calibrations, 25 hydrological years are identified among the total hydrological years available on the studied catchment (here 31 hydrological years, starting from 1976 and ending in 2008). Note that the number of 25-year combinations from a given set of 31 elements is 736,281 and thus that the 100 combinations tested here are only a sub-set of all the possible combinations. Unlike the P1 to P5 subperiods, the bootstrapped sub-periods are not independent and are quite similar: they have a majority of the 31 hydrological years observed in common and only differ by the absence/presence of a few years. The rainfall-runoff model is continuously run over the entire record period, but only the selected hydrological years are considered for the computation of the objective function. Note that bootstrap techniques have already been used for the estimation of hydrological parameter uncertainty (Ebtehaj et al., 2010; Selle \& Hannah, 2010).

iv. To highlight the influence of the August 2002 flood on the rainfall-runoff model calibration, the same bootstrap scheme has been repeated but the August 2002 data were systematically excluded from the computation of the objective function. Thus, even if the 2002 hydrological year is selected, the August 2002 month will not be considered for the calibration of the rainfallrunoff model. These parameter sets will be noted BSM1, BSM2, .., BSM100.

After each calibration, the MORDOR model was run on the whole period to enable efficiency calculations on all test sub-periods. 


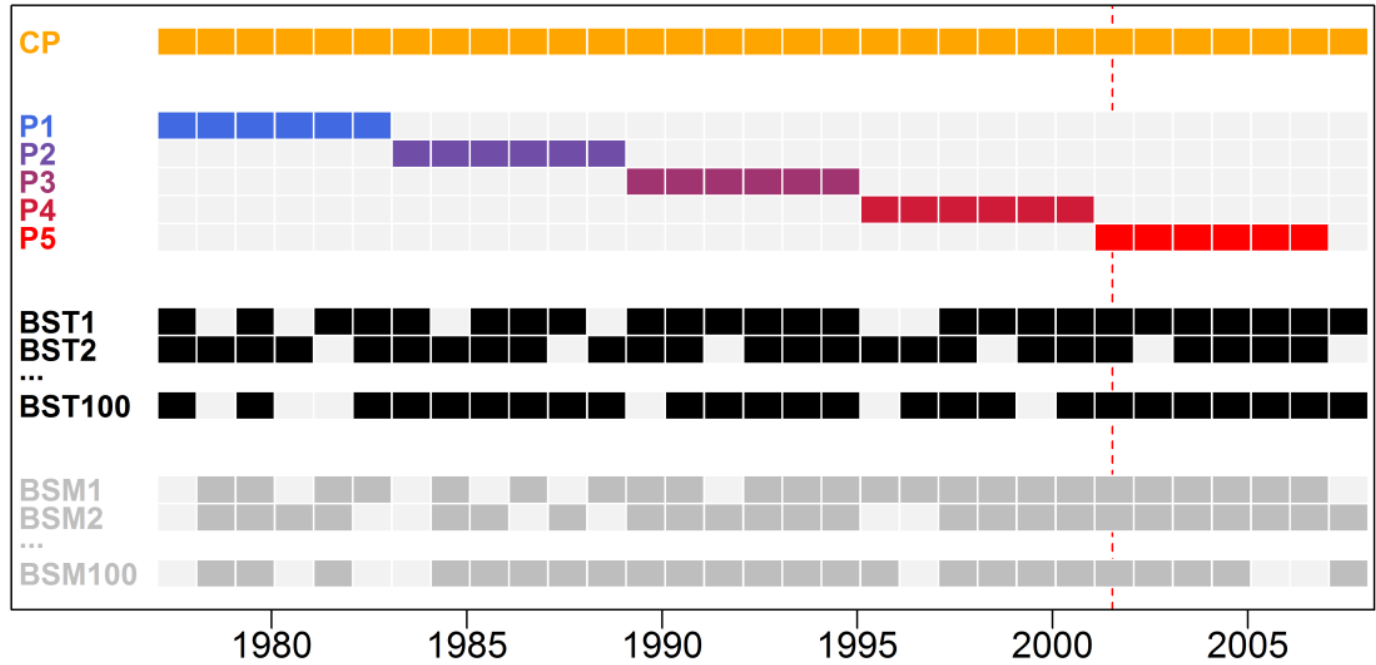

312

Fig. 2 Illustration of the different calibration strategies used for the calibration of the MORDOR rainfall-runoff model: calibration over the entire record period $(\mathrm{CP})$, calibrations over the five 6-year sub-periods (P1-P5), calibration over 100 25-year sub-periods generated through a block-bootstrap technique (BST1 to BST100) and calibration over 100 25-year sub-periods excluding the August 2002 observations, generated through a block-bootstrap technique (BSM1 to BSM100). The vertical dotted line indicates the 2002 flood event. 


\subsection{Performance of the MORDOR rainfall-runoff model}

Figure 3 presents a summary of the MORDOR performance obtained over the complete record period and over the five 6-year sub-periods, P1 to P5, both in terms of $\mathrm{OBJ}_{\mathrm{EDF}}$ (the calibration criterion, top panel), NSE (middle panel) and NSE $\mathrm{CDF}$ (bottom panel), and considering the different calibration options described above. MORDOR performance is generally good over the complete period, with the NSE score greater than 0.7 . However, there is also a substantial variability of NSE scores over the different 6-year sub-periods, with several NSE scores below 0.6.

In terms of $\mathrm{OBJ}_{\mathrm{EDF}}$, calibration performance is the poorest for the P3 (1989-1995) sub-period. The performance range obtained with bootstrap calibrations is rather narrow and median performance is generally similar to the $\mathrm{CP}$ parameter set performance. This is related to the similarity of the 25-year sub-periods as well as the similarity between the CP period and BS sub-periods, only differing by the presence and/or absence of several hydrological years. BSM calibrations (grey boxplots) generally perform better than the BST for the P1 to P4 sub-periods while they perform less well for the complete period (CP) and the P5 sub-period (which includes 2002), regarding the three different scores. Interestingly, a similar ranking of model performance is obtained for the complete period and the P5 evaluation periods, which are the two periods containing the August 2002 event. For these periods, the CP parameter set is the best parameter set, followed by the P5 parameter set. The P1 to P4 parameter sets perform poorly for P5 compared to the other ones, especially for the $\mathrm{NSE}_{\mathrm{CDF}}$ score. Finally, the BST calibrations (black boxplots) generally performed better than the BSM calibrations (excluding the August 2002 month). 
(a)

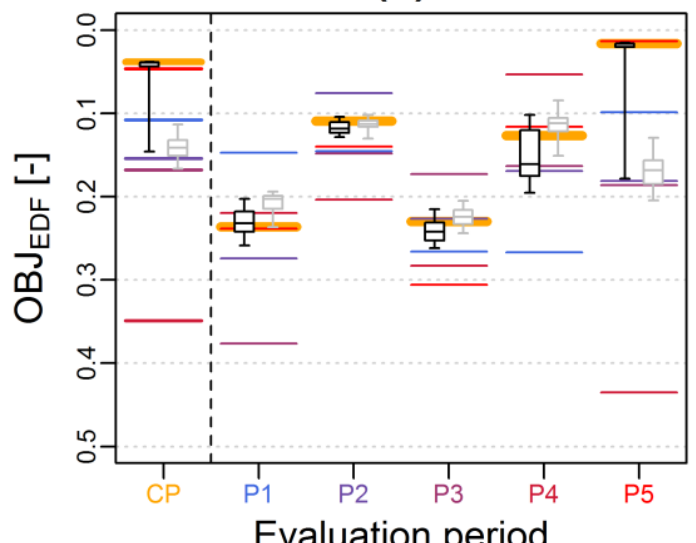

(b)

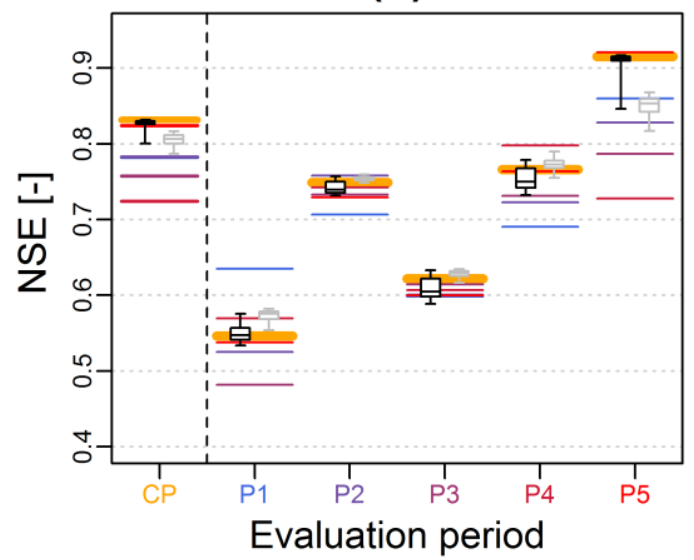

(c)

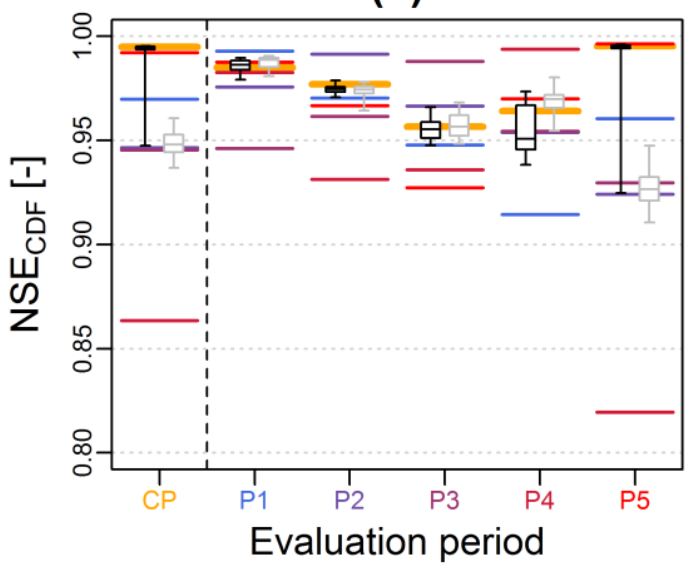

Calibration strategies

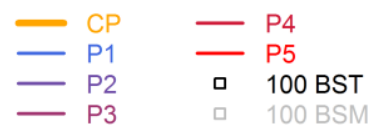

Fig. 3 MORDOR performance over six different evaluation periods: the complete period (1976-2008) and five 6-year subperiods (P1-P5), in terms of $\mathrm{OBJ}_{\mathrm{EDF}}$ (calibration criterion, top panel), NSE (middle panel) and $\mathrm{NSE}_{\mathrm{CDF}}$ (bottom panel), according to different calibration strategies. Boxplots show the $0.10,0.25,0.50,0.75$ and 0.90 percentiles of the performance distributions obtained with the BST and BSM (excluding the August 2002 month) bootstrap calibration strategies. 
348 Figure 4 shows Lorenz curves computed for each evaluation period and each 349 MORDOR parameter set. The Lorenz curve is classically used in economics; it was 350 introduced to represent the inequality of the wealth distribution, showing which 351 proportion of the population owns which proportion of the total wealth 352 (Lorenz, 1905). Here, the plotted Lorenz curves show the proportion of the total 353 evaluation series (time steps) as a function of the total model error (here the sum of 354 the squares of the model error), i.e. the cumulative distribution of ranked relative model errors. For example, considering the CP parameter set and evaluating its error over the CP period (orange line on the top left panel), the Lorenz curve reveals that around $80 \%$ of the total MORDOR model error is made on less than $15 \%$ of the total calibration period time steps. For the P4 parameter set (purple line), $80 \%$ of the total MORDOR model error is made on less than $2.5 \%$ of the total calibration period time steps. The complete analysis of the Lorenz curves shows first that P1 to P4 subperiods have similar error distributions considering the different calibration strategies. On average, $80 \%$ of the total error is made on 5 to $12 \%$ of the calibration period timesteps. For the complete period and the P5 sub-period (both including August 2002 flood), different Lorenz curves are obtained. For P1 to P4 parameter sets and bootstrap calibrations not containing the August 2002 flood, a large proportion of the total error is made on a smaller part of the total evaluation time steps, compared to the P5 and CP parameter sets.

The shape of each Lorenz curve can be summarized and quantified with the computation of the Gini index (Gini, 1912), which is the area between the line of perfect equality $(\mathrm{x}=\mathrm{y})$ and the computed Lorenz curve. The Gini coefficient ranges between 0 and 1: the higher the coefficient, the more uneven the distribution is. Such coefficients have been computed for each Lorenz curve and are indicated on each panel in Figure 4. The highest coefficient values are obtained for the CP and P5 periods, considering the $\mathrm{P} 1$ to $\mathrm{P} 4$ parameter sets and bootstrap calibrations not containing the August 2002 flood. This shows that for these sub-periods and parameter sets, a larger proportion of the total MORDOR model error is made on a smaller part of the evaluation series. 

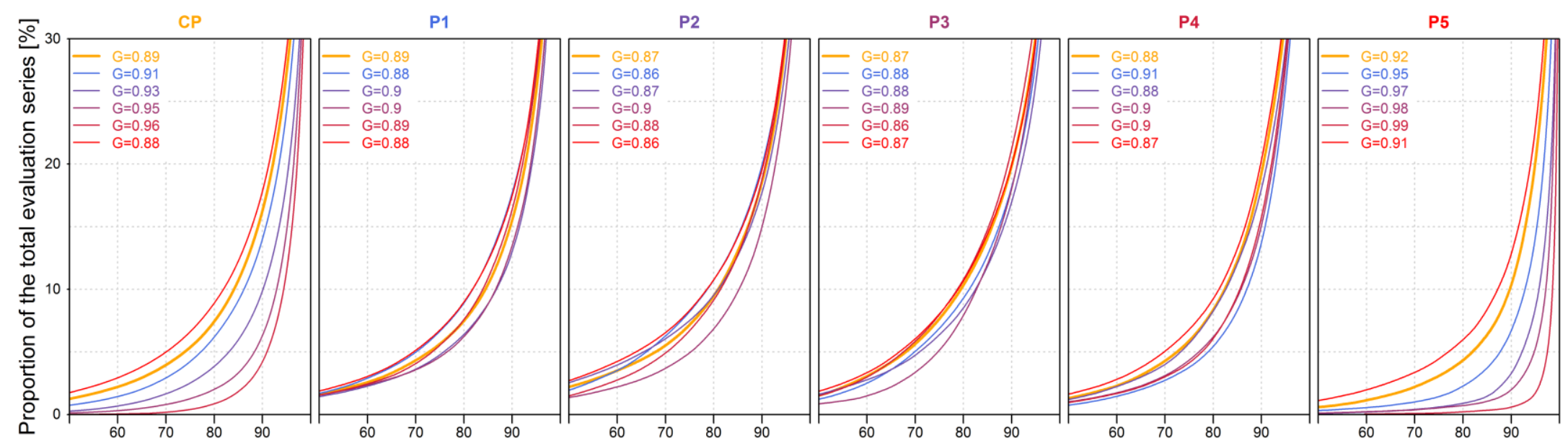

Calibration strategies
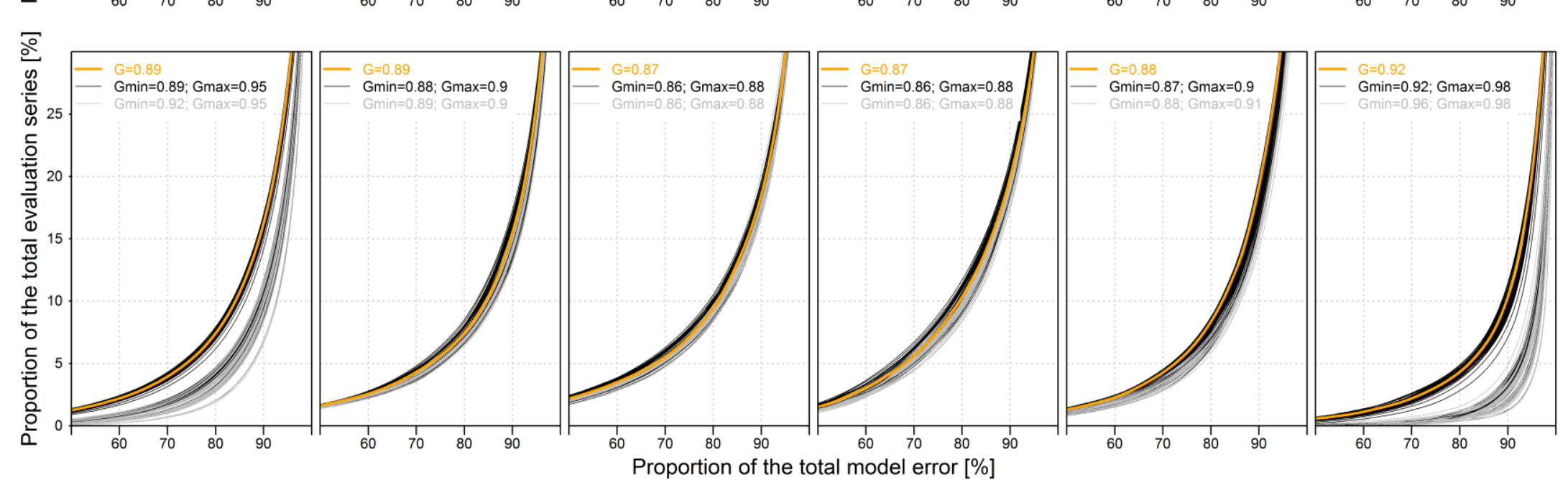

二 ${ }^{\mathrm{CP}}$

二 ${ }^{\mathrm{P} 1}$

— $\mathrm{P4}$
— ${ }^{2}$
$-100 \mathrm{BST}$

Fig. 4 Lorenz curves showing the proportion of the total evaluation series as a function of the total MORDOR model error, computed over six different evaluation periods:

the complete period (CP) and five 6-year sub-periods (P1-P5) and for different calibration strategies. Top row: (calibration on CP and P1-P5; and bottom row: calibration on

BST (black ines) and BSM (grey lines). 
In order to confirm the substantial influence of the August 2002 flood presence within the MORDOR calibration and evaluation period, a time series of MORDOR model's error is plotted in Figure 5, for the P5 sub-period (2001-2007) and for the CP, P1 to P5 parameter sets. In this figure, the time steps representing $80 \%$ of the model cumulated total error are plotted with a circle, whose size is proportional to the model error made. Note that for the CP and the P5 parameter sets (orange and red circles, respectively), error is made in calibration while for the other parameter sets, it is an error in validation. Again, errors made with the $\mathrm{CP}$ and the P5 parameter sets are more evenly distributed than errors made by the P1 to P4 parameter sets, and the proportion of the 2002 event in the total error appears smaller in the CP and P5 sets. For the P1 to P4 parameter sets, the main errors are mainly concentrated on the August 2002 flood event. The P1 parameter error distribution appears to be slightly different from the P2 to P4 sets, with large errors made on the August 2002 flood event for the P1 parameter set, while the P2 to P4 parameter sets induce huge errors made on the August 2002 flood event and also a large error made on the September 2008 flood event.

399
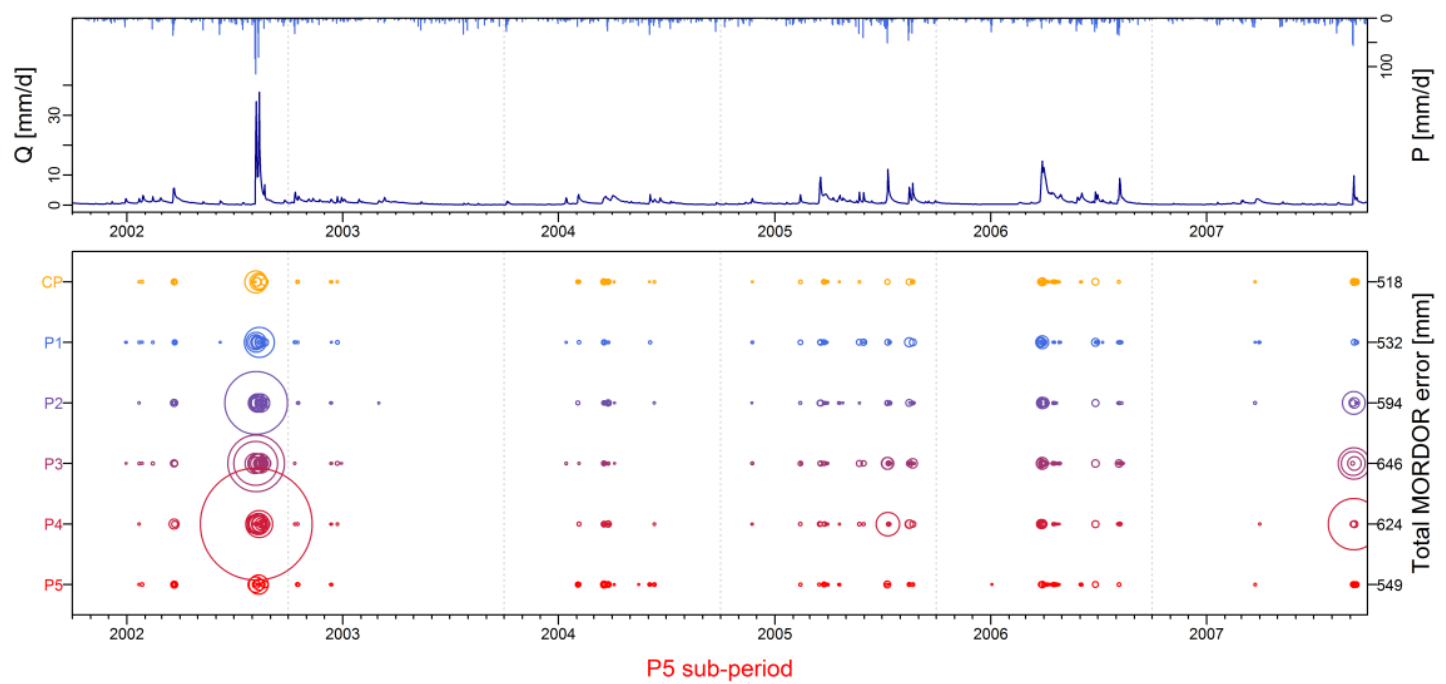

400

401

402

403

404

405

406

407

408

409

410

411

412

413

414

415

416

417

418

Fig. 5 (top) Time series of observed precipitation and streamflow Kamp catchment series for the P5 sub-period (2001-2007). (bottom) Time series of MORDOR model error on sub-period P5 for the CP and P1-P5 parameter sets: time steps where MORDOR error $>1 \mathrm{~mm} / \mathrm{d}$ is plotted with a circle of size proportional to the error.

Figure 6 zooms in on the MORDOR streamflow simulations of August 2002, using the different parameter sets obtained with the different calibration options. Remarkably, this event is well simulated by the CP and P5 parameter sets. Conversely, it is poorly represented when using the P1 to P4 parameter sets (top panel), with a particularly strong overestimation of the first flood peak ( $8^{\text {th }}$ of August) for the P2 to P4 parameter sets. In general, the P2 to P4 parameter sets induce an excessively responsive rainfall-runoff relationship by the MORDOR model. When considering bootstrap calibrations, two different MORDOR model behaviours seem to be obtained, depending on the presence of the August 2002 month within the calibration sub-periods. Rather logically, the August 2002 event is well simulated when it belongs to the calibration sub-period considered (centre panel), while it is poorly simulated with the parameter sets obtained with calibration sub-periods systematically excluding this event (bottom panel). Note that the few BST calibrations 
419 (centre panel) highly overestimating the first flood peak have all been obtained with 420 calibration sub-periods not containing the 2002 year.

An investigation of MORDOR internal state dynamics (not shown here) revealed that the responsive rainfall-runoff relationships simulated by several parameter sets are induced, for this catchment, by the value of one particular MORDOR parameter, $\mathrm{L}_{\text {MAX. }}$. This parameter is the maximum capacity of the $\mathrm{L}$ reservoir, which determines the partitioning between a direct runoff, an indirect runoff and a deep percolation. Thus, in the MORDOR model, when a large amount of water reaches this reservoir (which is the case for the August 2002 event) a low $\mathrm{L}_{\mathrm{MAX}}$ value implies that a large proportion of this water is considered as direct runoff, while a higher $\mathrm{L}_{\mathrm{MAX}}$ value yields a larger proportion of indirect runoff. Interestingly, all MORDOR calibrations that exclude the August 2002 period are characterized by small $\mathrm{L}_{\mathrm{MAX}}$ values, while all MORDOR calibration that include this event are characterized by high $\mathrm{L}_{\text {MAX }}$ values. It clearly shows the weight of the August 2002 event's on the MORDOR calibration and the event uniqueness according to the MORDOR model: the incoming rainfall for this event is so large - relative to the observed streamflow - that the MORDOR model needs to have a high $\mathrm{L}_{\mathrm{MAX}}$ value for considering a large proportion of this incoming water as indirect runoff and then not have a significant difference between observed and simulated streamflow values. In validation on this event, the parameter sets characterized by low $\mathrm{L}_{\mathrm{MAX}}$ values ( $\mathrm{P} 1$ to $\mathrm{P} 4, \mathrm{BSM}$ and $22 \mathrm{BST}$ calibrations) produce overly responsive rainfall-runoff relationships, with a substantial overestimation of the first flood peak (8 August) and an underestimation of the flood recession (e.g. 10 and 11 August). 

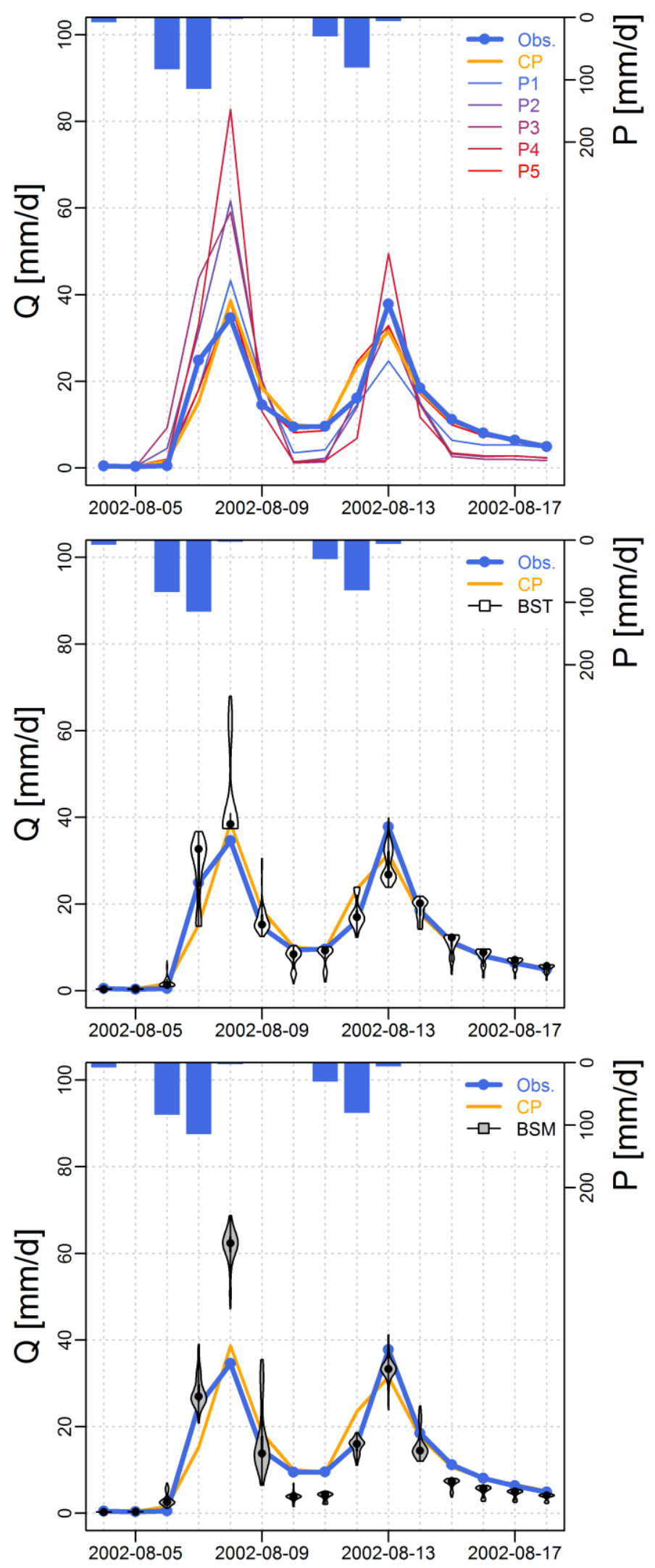

Fig. 6 August 2002 observed rainfall and streamflow series (solid and dotted lines) and MORDOR streamflow simulations considering different calibration strategies: (top) calibration over the five 6year subperiods (P1-P5); (centre) calibration over 100 25-year sub-periods (BST); and (bottom) calibration over 100 25-year sub-periods excluding the month August 2002 (BSM). 


\subsection{SCHADEX flood estimations}

Figure 7 presents the SCHADEX flood estimations calculated with the different MORDOR parameter sets, compared to the annual maximum series of daily streamflow of the Kamp catchment. When considering the CP parameter set for the MORDOR rainfall-runoff model, the $\mathrm{Q}_{1000}$ value estimated by the SCHADEX method is $318 \mathrm{~m}^{3} / \mathrm{s}$. The flood estimations computed with the P1 to P5 MORDOR parameter sets are presented on the first panel. The estimations computed using the P5 parameter set are very similar to the reference estimation, unlike estimations made using the P1 parameter set (with lower $\mathrm{Q}_{10}$ to $\mathrm{Q}_{1000}$ values) and estimations made using the $\mathrm{P} 2$ to P4 parameter sets (with substantially higher $\mathrm{Q}_{1000}$ values). A comparable range of flood estimations is obtained when considering the bootstrap calibrations. Two types of flood distributions are revealed, depending on the presence of the August 2002 within the calibration sub-periods: the flood estimations obtained with a calibration sub-period excluding the August 2002 event are higher than the other estimations, with median $Q_{1000}$ values close to $430 \mathrm{~m}^{3} / \mathrm{s}$ (median value of the 100 estimations presented in the bottom panel, in grey) and $300 \mathrm{~m}^{3} / \mathrm{s}$ (median value of the 100 estimations presented in the centre panel, in black), respectively.

This counterintuitive result is finally highlighted in Figure 8, where the left panel groups all the $\mathrm{Q}_{1000} \mathrm{SCHADEX}$ estimations obtained with the MORDOR parameter sets containing the August 2002 month within the calibration period, while the right panel groups all the $\mathrm{Q}_{1000}$ SCHADEX estimations obtained with the MORDOR parameter sets excluding the August 2002 month. This figure clearly shows that having the largest observed flood on the Kamp catchment within the MORDOR rainfall-runoff model calibration period produces lower SCHADEX flood estimations. In Figure 8, each $\mathrm{Q}_{1000}$ estimation has been plotted against its corresponding MORDOR $\mathrm{L}_{\text {MAX }}$ parameter value, identified as responsible for the excessively responsive August 2002 simulations (cf. Figure 6). Interestingly, the highest $\mathrm{Q}_{1000}$ estimations are obtained with the lowest $\mathrm{L}_{\mathrm{MAX}}$ values. The presence of the August 2002 event within the MORDOR calibration period thus induces a high $\mathrm{L}_{\mathrm{MAX}}$ parameter value and consequently a low $\mathrm{Q}_{1000}$ estimation. In this case, the $\mathrm{L}$ reservoir is able to transform large amounts of incoming rainfall into indirect runoff. 

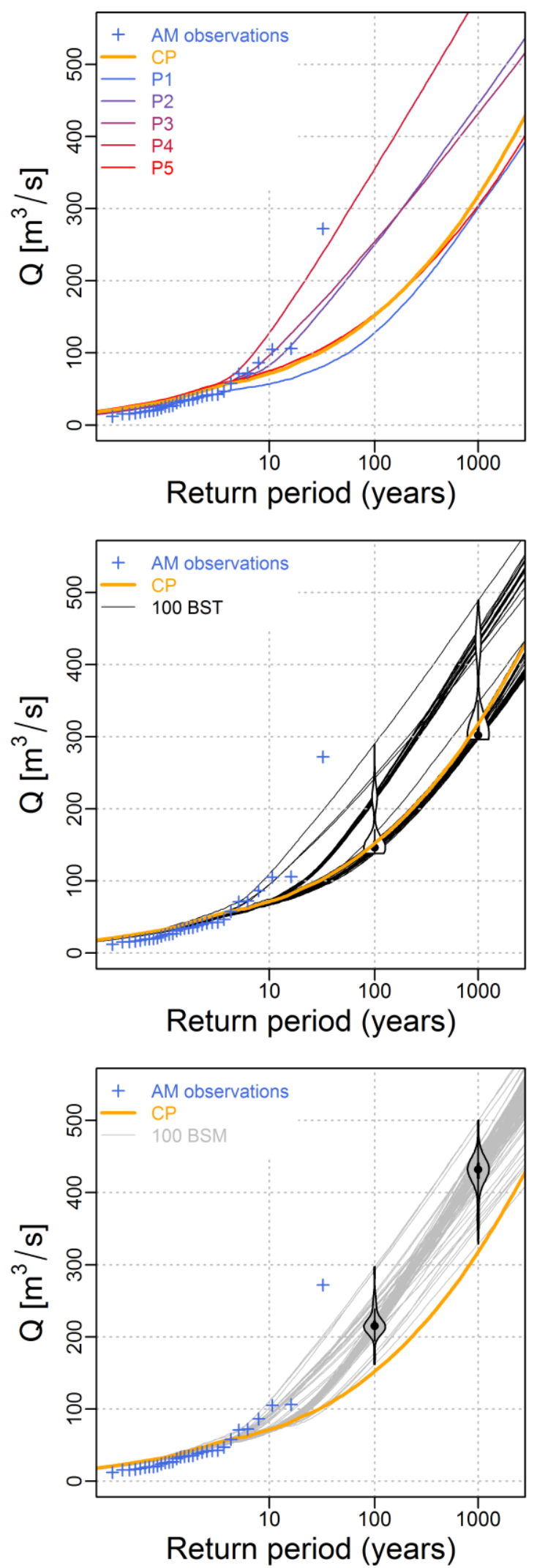

Fig. 7 Annual maximum (AM) of daily streamflow observations (+) compared to the SCHADEX reference flood estimation (large solid lines) and flood estimations performed considering different MORDOR calibration strategies: (top) calibration over the five 6-year sub-periods (P1-P5); (centre) calibration over 100 25-year sub-periods (BST); and (bottom) calibration over 100 25-year subperiods discarding the month August 2002. Violin plots represent the distribution of bootstrap flood estimations for the 100- and 1000-year return periods. 

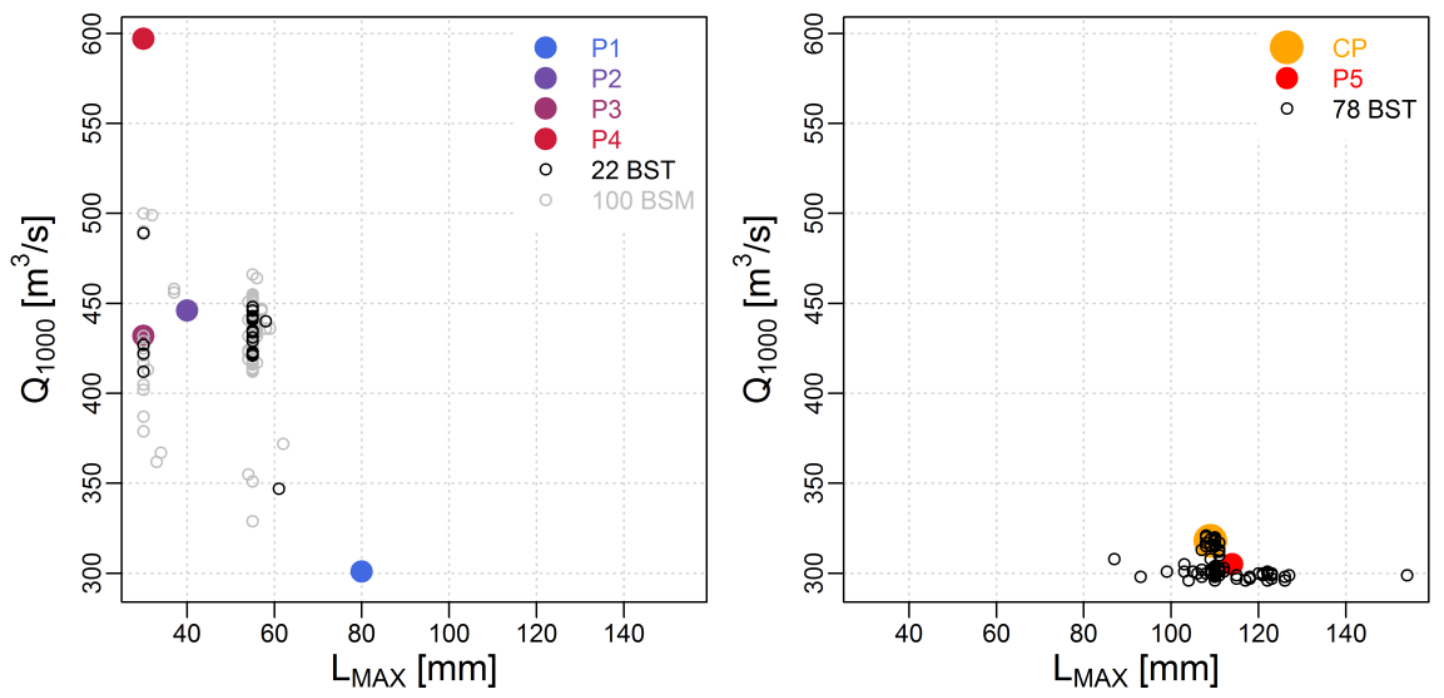

Fig. 8 SCHADEX $\mathrm{Q}_{1000}$ flood estimations plotted against the corresponding values of MORDOR 492 parameter, LMAX, both obtained with the MORDOR calibration including August 2002 (left) and excluding August 2002 (right). 


\section{DISCUSSION AND CONCLUSION}

The Kamp at Zwettl is an interesting case study for all hydrologists specializing in the art of flood frequency estimation, since it experienced a remarkable flood in August 2002 , reaching a value three times higher than the second largest observed flood in terms of peak value over the 55 years of available observations (Viglione et al., 2013). This case study provides a rare opportunity to investigate the impact of such a remarkable event on flood frequency estimation. Here, numerous extreme flood estimations were made on this catchment with the SCHADEX stochastic method, which is based on a conceptual rainfall-runoff model. Following the calibration protocol of the 2013 "Hydrology under change" IAHS workshop proposed by Thirel et al. (2014, this issue), the rainfall-runoff model was calibrated over five 6-year subperiods. Additionally, bootstrap calibrations were performed, following the methodology proposed by Brigode et al. (2014). In total, 206 calibrations of the MORDOR rainfall-runoff model were performed in this study, each of them used for producing different SCHADEX flood estimations.

The results confirmed the usefulness of the multi-period and bootstrap testing schemes to identify the dependence of model performance and flood estimates on the information contained in the calibration period and the presence of large flood events. As already pointed out by Viglione et al. (2013), the August 2002 event appears to play a key role in the flood frequency estimation on the Kamp River. Here, the presence of the event within the calibration sub-periods strongly influences the rainfall-runoff model calibration, the validation performance and the extreme flood estimations. All the parameter sets obtained with calibration periods that do not contain the August 2002 month perform poorly on the evaluation periods containing this event. Those parameter sets are characterized by an excessively responsive rainfall-runoff transformation, while the other ones simulate smoother hydrographs. An investigation of the MORDOR model's internal states reveals that one parameter ( $\mathrm{L}_{\mathrm{MAX}}$ ) is responsible for this particular simulation dynamic, and that the $\mathrm{L}_{\mathrm{MAX}}$ value obtained after calibration depends on the presence or absence of the August 2002 flood within the calibration period. Those "responsive" parameter sets obtained when the August 2002 event is excluded from the calibration period produce higher extreme flood estimations compared to the other parameter sets, confirming the findings of Brigode et al. (2014). Thus, $Q_{1000}$ estimates were much higher when model calibration did not include the large 2002 flood event. Interestingly, this sensitivity to the presence of the August 2002 flood is contrary (and thus counterintuitive) to the sensitivity obtained when applying a classical flood frequency analysis method (i.e. statistical estimation of flood quantiles using only streamflow series), highlighted by Viglione et al. (2013, Figure 3a and Figure 3b).

The bootstrap calibration methodology is shown to be a useful tool for an objective quantification of the model's dependence on the calibration period, considering the rainfall-runoff simulations and the extreme flood estimations. Computing a rigorous statistical confidence interval would require more statistical processing, but it nevertheless provides a "first guess" of the uncertainty associated with the calibration period and a range of extreme flood estimations.

Graphical and numerical tools have also been proposed in this study in order to highlight the influence of particular flood events on the calibration of rainfall-runoff 
models. Lorenz curves and the Gini coefficient provide a simple but efficient way to characterize the distribution of model errors and could be very useful to detect calibration periods where a few time steps cause a large proportion of the model's errors. In this regard, it could be interesting to compare, for different rainfall-runoff models and different catchments, whether the events selected by this kind of analysis as "strongly influencing the model calibration" are the same as the ones selected by other approaches such as DYNIA (Wagener et al., 2003) or ICE (Singh \& Bárdossy, 2012).

Given the dominating impact of the August 2002 data, one could wonder whether in practice a hydrologist engineer working on extreme flood estimation on the Kamp catchment should consider discarding the August 2002 data. On one hand, if he is applying a classical flood frequency analysis method, considering both the observed flood series and additional information such as historical floods or regional information is necessary to significantly reduce the weight of the August 2002 event and thus the flood estimation uncertainty. On the other hand, if he is applying a flood simulation method based on a rainfall-runoff model (e.g. SCHADEX), it would be in principle more appropriate to consider this type of flood events for the rainfall-runoff model calibration, because it enables the model to be trained on exceptional floods and thus to have the opportunity to identify the high flood-prevailing processes, which could differ from current floods (e.g. Rogger et al., 2012). However, the rainfallrunoff model robustness issue addressed in this case study (illustrated in Figures 5 and 6 for example) could be used as "process-based arguments" for an expert rainfallrunoff modeller who believes more in his model than in the observed data to discard particular flood event data.

In both cases, the question of the uncertainty of the rainfall and streamflow measurement of such events needs to be investigated further. For example, Lang et al. (2010) suggested that numerous French gauging streamflow stations are not reliable for floods with a return period higher than 2 years. For the Kamp catchment, Figure 9 shows pictures of the gauging station (at Zwettl (Bahnbrücke), station ID 207944) and flood tracks left by the August 2002 flood event, illustrating the potentially considerable uncertainty of streamflow measurement for this event. The Kamp River was clearly out of its banks and thus out of the usual streamflow rating curve. An interesting perspective would be to quantify the measurement uncertainty of this event and then recalibrate the MORDOR model before performing new SCHADEX flood estimations.

\section{Acknowledgements}

The assistance of Dr. Guillaume Thirel (Irstea), Prof. Ralf Merz (UFZ) and Prof. Juraj Parajka (Vienna University of Technology) with the Kamp River data set is gratefully acknowledged. The authors thank the anonymous reviewers and the Associate Editor, Dr. Alberto Viglione, for their constructive comments which helped improve the quality of the manuscript. Finally, the authors would like to thank Rémy Garçon (EDF-DTG) for his constrictive comments. 


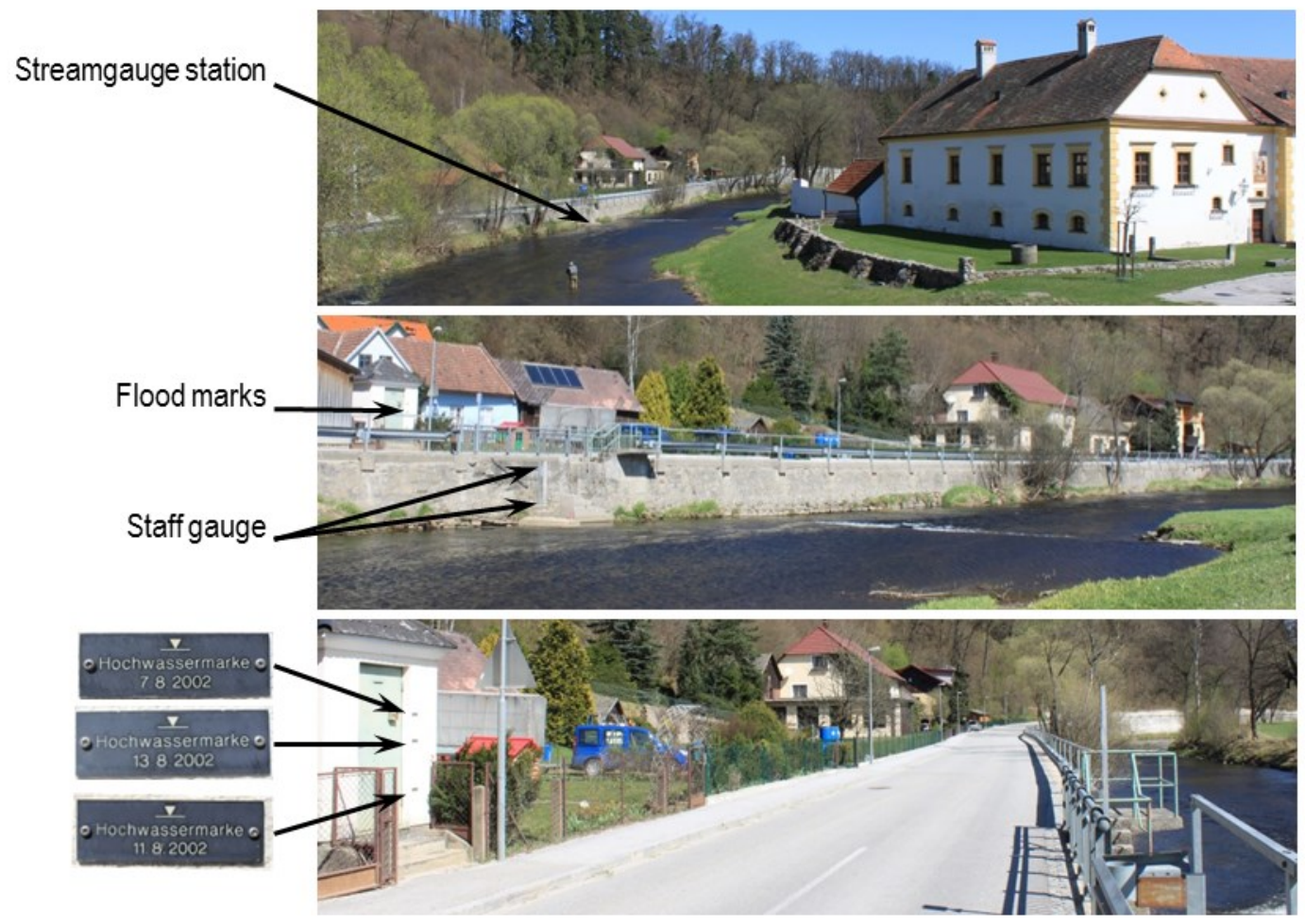

590 Fig. 9 Zwettl (Bahnbrücke, ID: 207944) streamgauge station and Kamp River. The bottom panel shows 591 the August 2002 flood marks. Photos: P. Brigode, April 2011. 


\section{REFERENCES}

Andréassian, V., Hall, A., Chahinian, N. \& Schaake, J. (2006) Large sample basin experiments for hydrological model parameterization: results of the Model Parameter Experiment (MOPEX). In: Large sample basin experiments for hydrological model parameterization: results of the model parameter experiment (MOPEX) IAHS Publication 307, 346. Retrieved from http://www.cabdirect.org/abstracts/20073200660.html

Andréassian, V., Moine, N. Le, Perrin, C., Ramos, M.-H., Oudin, L., Mathevet, T., Lerat, J., et al. (2012) All that glitters is not gold: the case of calibrating hydrological models. Hydrological Processes 26(14), 2206-2210. doi:10.1002/hyp.9264

Berthet, L., Andréassian, V., Perrin, C. \& Loumagne, C. (2010) How significant are quadratic criteria? Part 2. On the relative contribution of large flood events to the value of a quadratic criterion. Hydrological Sciences Journal 55(6), 10631073. doi:10.1080/02626667.2010.505891

Beven, K. \& Westerberg, I. (2011) On red herrings and real herrings: disinformation and information in hydrological inference. Hydrol. Process. 25(10), 16761680. doi:10.1002/hyp.7963

Blöschl, G., Nester, T., Komma, J., Parajka, J. \& Perdigão, R. A. P. (2013) The June 2013 flood in the Upper Danube Basin, and comparisons with the 2002, 1954 and 1899 floods. Hydrol. Earth Syst. Sci. 17(12), 5197-5212. doi:10.5194/hess-17-5197-2013

Brigode, P., Bernardara, P., Gailhard, J., Garavaglia, F., Ribstein, P. \& Merz, R. (2013b) Optimization of the geopotential heights information used in a rainfall-based weather patterns classification over Austria. International Journal of Climatology 33(6), 1563-1573. doi:10.1002/joc.3535

Brigode, P., Bernardara, P., Paquet, E., Gailhard, J., Garavaglia, F., Merz, R., Mićović, Z., et al. (2014) Sensitivity analysis of SCHADEX extreme flood estimations to observed hydrometeorological variability. Water Resources Research. doi:10.1002/2013WR013687

Brigode, P., Oudin, L. \& Perrin, C. (2013a) Hydrological model parameter instability: A source of additional uncertainty in estimating the hydrological impacts of climate change? Journal of Hydrology 476(0), 410-425. doi:10.1016/j.jhydrol.2012.11.012

Coron, L., Andréassian, V., Perrin, C., Lerat, J., Vaze, J., Bourqui, M. \& Hendrickx, F. (2012) Crash testing hydrological models in contrasted climate conditions: an experiment on 216 Australian catchments. Water Resour. Res. 48, W05552. doi:10.1029/2011WR011721

Donnelly-Makowecki, L. M. \& Moore, R. D. (1999) Hierarchical testing of three rainfall-runoff models in small forested catchments. Journal of Hydrology 219(3-4), 136-152. doi:10.1016/S0022-1694(99)00056-6

Duan, Q., Sorooshian, S. \& Gupta, V. (1992) Effective and efficient global optimization for conceptual rainfall-runoff models. Water Resour. Res. 28(4), PP. 1015-1031. doi:199210.1029/91WR02985

Ebtehaj, M., Moradkhani, H. \& Gupta, H. V. (2010) Improving robustness of hydrologic parameter estimation by the use of moving block bootstrap resampling. Water Resour. Res. 46(7), W07515. doi:10.1029/2009WR007981

Franchini, M. (1996) Use of a genetic algorithm combined with a local search method for the automatic calibration of conceptual rainfall-runoff models. 
Hydrological Sciences doi:10.1080/02626669609491476
41(1),

21-39.

Garavaglia, F., Gailhard, J., Paquet, E., Lang, M., Garçon, R. \& Bernardara, P. (2010) Introducing a rainfall compound distribution model based on weather patterns sub-sampling. Hydrol. Earth Syst. Sci. 14(6), 951-964. doi:10.5194/hess-14951-2010

Garçon, R. (1999) Modèle global pluie-débit pour la prévision et la prédétermination des crues. La Houille Blanche (7-8), 88-95. doi:10.1051/1hb/1999088

Gharari, S., Hrachowitz, M., Fenicia, F. \& Savenije, H. H. G. (2013) An approach to identify time consistent model parameters: sub-period calibration. Hydrol. Earth Syst. Sci. 17(1), 149-161. doi:10.5194/hess-17-149-2013

Gini, C. (1912) Variabilità e mutabilità. Reprinted in Memorie di metodologica statistica (Ed. Pizetti E, Salvemini, T). Rome: Libreria Eredi Virgilio Veschi 1. Retrieved from http://adsabs.harvard.edu/abs/1912vamu.book.....G

Grubbs, F. E. (1969) Procedures for Detecting Outlying Observations in Samples. Technometrics 11(1), 1-21. doi:10.1080/00401706.1969.10490657

Herman, J. D., Reed, P. M. \& Wagener, T. (2013) Time-varying sensitivity analysis clarifies the effects of watershed model formulation on model behavior. Water Resources Research. doi:10.1002/wrcr.20124

Hrachowitz, M., Savenije, H. H. G., Blöschl, G., McDonnell, J. J., Sivapalan, M., Pomeroy, J. W., Arheimer, B., et al. (2013) A decade of Predictions in Ungauged Basins (PUB) - a review. Hydrological Sciences Journal 58(6), 1198-1255. doi:10.1080/02626667.2013.803183

Jarvis, A., Reuter, H. I., Nelson, A. \& Guevara, E. (2008) Hole-filled SRTM for the globe Version 4 (available from the CGIAR-CSI SRTM 90m Database). Retrieved from http://srtm.csi.cgiar.org

Katz, R. W., Parlange, M. B. \& Naveau, P. (2002) Statistics of extremes in hydrology. Advances in Water Resources 25(8-12), 1287-1304. doi:10.1016/S03091708(02)00056-8

Klemeš, V. (1986) Operational testing of hydrological simulation models. Hydrological Sciences Journal 31(1), 13. doi:10.1080/02626668609491024

Komma, J., Reszler, C., Blöschl, G. \& Haiden, T. (2007) Ensemble prediction of floods - catchment non-linearity and forecast probabilities. Natural Hazards and Earth System Sciences 7(4), 431-444. doi:10.5194/nhess-7-431-2007

Koutsoyiannis, D. (2006) Nonstationarity versus scaling in hydrology. Journal of Hydrology 324(1-4), 239-254. doi:10.1016/j.jhydrol.2005.09.022

Laio, F., Allamano, P. \& Claps, P. (2010) Exploiting the information content of hydrological outliers" for goodness-of-fit testing. Hydrol. Earth Syst. Sci. 14(10), 1909-1917. doi:10.5194/hess-14-1909-2010

Lamb, R. (1999) Calibration of a conceptual rainfall-runoff model for flood frequency estimation by continuous simulation. Water Resources Research 35(10), 3103-3114. doi:10.1029/1999WR900119

Lang, M., Pobanz, K., Renard, B., Renouf, E. \& Sauquet, E. (2010) Extrapolation of rating curves by hydraulic modelling, with application to flood frequency analysis. Hydrological Sciences Journal 55(6), 883-898. doi:10.1080/02626667.2010.504186

Lawrence, D., Paquet, E., Gailhard, J. \& Fleig, A. K. (2014) Stochastic semicontinuous simulation for extreme flood estimation in catchments with combined rainfall-snowmelt flood regimes. Nat. Hazards Earth Syst. Sci. 14(5), 1283-1298. doi:10.5194/nhess-14-1283-2014 
Lorenz, M. O. (1905) Methods of Measuring the Concentration of Wealth. Publications of the American Statistical Association 9(70), 209-219. doi: $10.2307 / 2276207$

Mathevet, T. (2005) Quels modèles pluie-débit globaux au pas de temps horaire? Développements empiriques et comparaison de modèles sur un large échantillon de bassins versants. ENGREF, Paris.

Merz, R., Parajka, J. \& Blöschl, G. (2011) Time stability of catchment model parameters: Implications for climate impact analyses. Water Resour. Res. 47, 17 PP. doi:10.1029/2010WR009505

Milly, P. C. D., Betancourt, J., Falkenmark, M., Hirsch, R. M., Kundzewicz, Z. W., Lettenmaier, D. P. \& Stouffer, R. J. (2008) Stationarity Is Dead: Whither Water Management? Science 319(5863), 573-574. doi:10.1126/science. 1151915

Montanari, A. (2012) Hydrology of the Po River: looking for changing patterns in river discharge. Hydrol. Earth Syst. Sci. 16(10), 3739-3747. doi:10.5194/hess16-3739-2012

Montanari, A., Young, G., Savenije, H. H. G., Hughes, D., Wagener, T., Ren, L. L., Koutsoyiannis, D., et al. (2013) 'Panta Rhei-Everything Flows': Change in hydrology and society - The IAHS Scientific Decade 2013-2022. Hydrological Sciences Journal 58(6), 1256-1275. doi:10.1080/02626667.2013.809088

Muñoz, E., Arumí, J. L. \& Rivera, D. (2013) Watersheds are not static: Implications of climate variability and hydrologic dynamics in modeling. Bosque (Valdivia) 34(1), 7-11. doi:10.4067/S0717-92002013000100002

Nash, J. E. \& Sutcliffe, J. V. (1970) River flow forecasting through conceptual models part I - A discussion of principles. Journal of Hydrology 10(3), 282290. doi:10.1016/0022-1694(70)90255-6

Nicolle, P., Pushpalatha, R., Perrin, C., François, D., Thiéry, D., Mathevet, T., Lay, M. Le, et al. (2014) Benchmarking hydrological models for low-flow simulation and forecasting on French catchments. Hydrol. Earth Syst. Sci. 18(8), 2829-2857. doi:10.5194/hess-18-2829-2014

Paquet, E., Garavaglia, F., Garçon, R. \& Gailhard, J. (2013) The SCHADEX method: A semi-continuous rainfall-runoff simulation for extreme flood estimation. Journal of Hydrology 495, 23-37. doi:10.1016/j.jhydrol.2013.04.045

Peel, M. C. \& Blöschl, G. (2011) Hydrological modelling in a changing world. Progress in Physical Geography 35(2), 249-261.

Perrin, C., Oudin, L., Andreassian, V., Rojas-Serna, C., Michel, C. \& Mathevet, T. (2007) Impact of limited streamflow data on the efficiency and the parameters of rainfall-runoff models. Hydrological Sciences Journal 52(1), 131-151. doi:10.1623/hysj.52.1.131

Rogger, M., Pirkl, H., Viglione, A., Komma, J., Kohl, B., Kirnbauer, R., Merz, R., et al. (2012) Step changes in the flood frequency curve: Process controls. Water Resour. Res. 48, 15 PP. doi:201210.1029/2011WR011187

Seibert, J. (2003) Reliability of model predictions outside calibration conditions. Nordic Hydrology 34(5), 477-492. doi:10.2166/nh.2003.028

Seibert, J. \& Beven, K. J. (2009) Gauging the ungauged basin: how many discharge measurements are needed? Hydrology and Earth System Sciences 13(6), 883892. doi:10.5194/hess-13-883-2009

Selle, B. \& Hannah, M. (2010) A bootstrap approach to assess parameter uncertainty in simple catchment models. Environmental Modelling \& Software 25(8), 919-926. doi:10.1016/j.envsoft.2010.03.005 
Singh, S. K. \& Bárdossy, A. (2012) Calibration of hydrological models on hydrologically unusual events. Advances in Water Resources 38, 81-91.

Singh, S. K., Liang, J. \& Bárdossy, A. (2012) Improving the calibration strategy of the physically-based model WaSiM-ETH using critical events. Hydrological Sciences Journal 57(8), 1487-1505. doi:10.1080/02626667.2012.727091

Thirel, G., Andréassian, V., Perrin, C., Audouy, J.-N., Berthet, L., Edwards, P., Folton, N., et al. (2014) Hydrology under change. An evaluation protocol to investigate how hydrological models deal with changing catchments. Hydrol. Sci. J. (Special Issue).

Vaze, J., Post, D. A., Chiew, F. H. S., Perraud, J.-M., Viney, N. R. \& Teng, J. (2010) Climate non-stationarity - Validity of calibrated rainfall-runoff models for use in climate change studies. Journal of Hydrology 394(3-4), 447-457. doi:16/j.jhydrol.2010.09.018

Viglione, A., Chirico, G. B., Komma, J., Woods, R., Borga, M. \& Blöschl, G. (2010) Quantifying space-time dynamics of flood event types. Journal of Hydrology 394(1-2), 213-229. doi:10.1016/j.jhydrol.2010.05.041

Viglione, A., Merz, R., Salinas, J. L. \& Blöschl, G. (2013) Flood frequency hydrology: 3. A Bayesian analysis. Water Resources Research 49(2), 675692. doi:10.1029/2011WR010782

Wagener, T. \& Kollat, J. (2007) Numerical and visual evaluation of hydrological and environmental models using the Monte Carlo analysis toolbox. Environmental Modelling \& Software 22(7), 1021-1033. doi:10.1016/j.envsoft.2006.06.017

Wagener, T., McIntyre, N., Lees, M. J., Wheater, H. S. \& Gupta, H. V. (2003) Towards reduced uncertainty in conceptual rainfall-runoff modelling: dynamic identifiability analysis. Hydrological Processes 17(2), 455-476. doi:10.1002/hyp.1135

Wang, Q. J. (1991) The Genetic Algorithm and Its Application to Calibrating Conceptual Rainfall-Runoff Models. Water Resour. Res. 27(9), 2467-2471. doi:10.1029/91WR01305

Wang, Q. J. (1997) Using genetic algorithms to optimise model parameters. Environmental Modelling \& Software 12(1), 27-34. doi:10.1016/S13648152(96)00030-8

Ward, P. J., Eisner, S., Flörke, M., Dettinger, M. D. \& Kummu, M. (2014) Annual flood sensitivities to El Niño-Southern Oscillation at the global scale. Hydrol. Earth Syst. Sci. 18(1), 47-66. doi:10.5194/hess-18-47-2014

Zalachori, I., Ramos, M.-H., Garçon, R., Mathevet, T. \& Gailhard, J. (2012) Statistical processing of forecasts for hydrological ensemble prediction: a comparative study of different bias correction strategies. Adv. Sci. Res. 8, 135141. doi:10.5194/asr-8-135-2012 